\title{
Islam Rimba: Islamic philosophy and local culture engagement in Sumatera
}

\begin{tabular}{|c|c|}
\hline $\begin{array}{l}\text { Authors: } \\
\text { Waryono War } \\
\text { M. Nurdin Zur } \\
\text { M. Anwar Nav } \\
\text { Elmansyah Eln }\end{array}$ & $\begin{array}{l}\text { lono }{ }^{1} \text { (1) } \\
\mathrm{di}^{2} \text { (1) } \\
\text { lawi } \\
\text { lansyah }\end{array}$ \\
\hline $\begin{array}{l}\text { Affiliations: } \\
\text { 1Department } \\
\text { Islam,Pasca Sa } \\
\text { Universitas IsI } \\
\text { (UIN) Sunan K } \\
\text { Yogyakarta, In }\end{array}$ & $\begin{array}{l}\text { tudi } \\
\text { rjana, } \\
\text { am Negeri } \\
\text { alijaga, } \\
\text { donesia }\end{array}$ \\
\hline $\begin{array}{l}{ }^{2} \text { Fisioterapi, II } \\
\text { Universitas Ai } \\
\text { Yogyakarta, In }\end{array}$ & $\begin{array}{l}\text { nu Kesehatan, } \\
\text { yiyah, } \\
\text { donesia }\end{array}$ \\
\hline $\begin{array}{l}\text { }{ }^{\text {Hukum Kelua }} \\
\text { Syari'ah, Seko } \\
\text { Agama Islam } \\
\text { Bawang, Lamp }\end{array}$ & $\begin{array}{l}\text { ga Islam, } \\
\text { ah Tinggi } \\
\text { STAI) Tulang } \\
\text { ung, Indonesia }\end{array}$ \\
\hline $\begin{array}{l}{ }^{4} \text { Studi Agama } \\
\text { Fakultas Ushu } \\
\text { dan Dakwah ( } \\
\text { Pontianak, Inc }\end{array}$ & $\begin{array}{l}\text { Agama, } \\
\text { uddin, Adab } \\
\text { UAD), IAIN } \\
\text { onesia }\end{array}$ \\
\hline $\begin{array}{l}\text { Correspondin } \\
\text { Waryono War } \\
\text { waryono.abdu } \\
\text { com }\end{array}$ & $\begin{array}{l}\text { author: } \\
\text { /ono, } \\
\text { Igafur@gmail. }\end{array}$ \\
\hline $\begin{array}{l}\text { Dates: } \\
\text { Received: } 23 \\
\text { Accepted: } 15 \\
\text { Published: } 05\end{array}$ & $\begin{array}{l}\text { eb. } 2021 \\
\text { Apr. } 2021 \\
\text { Aug. } 2021\end{array}$ \\
\hline $\begin{array}{l}\text { How to cite th } \\
\text { Waryono, W., } \\
\text { Nawawi, M.A. } \\
\text { 2021, 'Islam Ri } \\
\text { philosophy an } \\
\text { engagement in } \\
\text { Teologiese Stu } \\
\text { Studies 77(4), } \\
\text { doi.org/10.41C } \\
\text { v77i4.6561 }\end{array}$ & $\begin{array}{l}\text { is article: } \\
\text { uhdi, M.N., } \\
\text { \& Elmansyah, E., } \\
\text { nba: Islamic } \\
\text { local culture } \\
\text { Sumatera', HTS } \\
\text { lies/ Theological } \\
\text { 6561. https:// } \\
\text { 2/hts. }\end{array}$ \\
\hline $\begin{array}{l}\text { Copyright: } \\
\text { C 2021. The } \\
\text { Licensee: AOS } \\
\text { is licensed un } \\
\text { Creative Comr } \\
\text { Attribution Lic }\end{array}$ & $\begin{array}{l}\text { uthors. } \\
\text { S. This work } \\
\text { ler the } \\
\text { hons } \\
\text { ense. }\end{array}$ \\
\hline Read online: & \\
\hline 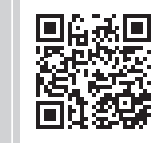 & $\begin{array}{l}\text { Scan this QR } \\
\text { code with your } \\
\text { smart phone or } \\
\text { mobile device } \\
\text { to read online. }\end{array}$ \\
\hline
\end{tabular}

This research aims to reveal the historical roots and elements of the background for the formation of the Orang Rimba's religion. This study is based on field research with a descriptive approach of religious phenomenon. The research derives some conclusions: (1) the Orang Rimba is monotheist, that is, they are not adherents to dynamism, polytheism, or animism as it has been understood. (2) The history of the Orang Rimba's religion is affected by two elements; namely, Rimba culture and Islamic culture. (3) Evidence suggests that Islam is one element of Orang Rimba's religion as the following: (a) Mantra of Getting Honey, such as Basmallah, Allah, Istighfar, Muhammad and Ya Karim; (b) Orang Rimba Faith in God, the Prophet Muhammad, the Angel and Doomsday; (c) the values of the ceremony of Death: Ratib Laa Ilaha Illallah; and (d) the values of the ceremony Berdekir. (4) It has proved the existence of a new theory about the spread of Islam in the Suku Anak Dalam community since the 14th century and at the same time undermined the old theory of the Orang Rimba's religion that has been misunderstood over the years.

Contribution: Researchers can use this new theory's findings as reference material on the Orang Rimba's religion (Suku Anak Dalam). They can also use this theory to compare other views about the Orang Rimba's religion.

Keywords: Orang Rimba; religion; faith; mantra; Islam; al-Qur'an.

\section{Introduction}

Orang Rimba or Orang Kubu is the name of a Suku Anak Dalam (SAD) in Indonesia, which is almost extinct. Suku Anak Dalam lives in the jungle of Bukit Duabelas. They may have existed long before, probably around the 14th century, the colonisers came to Indonesia, which is around the 16th century. According to the oral history, Orang Rimba is a descendant of the Sriwijaya Kingdom who fled because of war. During the Majapahit army's last attack against Sriwijaya in the 14th century, there was massive displacement into the forest interior. Some of the refugees entered the Jambi area (Batanghari), and some fled and hid in the jungle of Bukit Duabelas. The people who fled to Bukit Duabelas became known as the Orang Kubu or the Orang Rimba (Simanjuntak 2008:243).

Not many indigenous tribes in Indonesia are able to maintain their identity today. One of them is the Orang Rimba community. They live by moving from one place to another (nomadic). The Orang Rimba lifestyle, like the Badwi tribe, does not have a permanent place to live, moving in search of springs and grasslands. Until now, the Orang Rimba have not been able to settle permanently. It is more because of the pattern and lifestyle that still depend on the forest, not on cultivation (Abdurrahman et al. 2012).

There are various reasons as to why they do not want to settle in one place. One of them is melangun [move places because a jungle resident has died]. According to the Orang Rimba belief, if any of its residents dies, the place of living must be abandoned because if it does not happen, then the gods will curse them. The real reason is that the family left behind can easily forget the sadness of the death of the person, avoid enemies and find new sources of food by relying on fruits in the forest or hunting (Chief of the tribe in Bukit Duabelas, 17 December 2013).

The Orang Rimba tribe is known to be very close to the outside world. They have their own unique and exciting religions and customs to study. In every religious or traditional ceremony, the Orang Rimba cannot leave the mantras. For example, the recitation of mantras is done when they want to take honey from the Sialang tree (which reaches up to 90 metres high), or when they perform rites at the time of a ceremony of god worship, and at the time of death of a person. The mantras used by the Orang Rimba are an inseparable part of their religious life. 
No one knows about the religion of Orang Rimba. But, in the initial research, the researcher found a unique thing. It is about the mantra that they recited in a ceremony - the mantra has Islamic words.

It is interesting to note that every mantra that the Orang Rimba read contains Islamic elements, especially in terms of the lafadz [Arabic words] used. The details of Islamic culture are visible in the incantations and several elements of the Orang Rimba's beliefs and customs. It gives a sign that there is a cultural acculturation between the Orang Rimba's religion and Islam. So far, Orang Rimba's religion is synonymous with belief in gods (polytheism), whilst in Islam it is believed that God is one (monotheism). The distinction between the two different cultures is interesting to study.

\section{Research method and design}

This study used a phenomenological approach to religion and cultural acculturation. The phenomenological approach used here is the phenomenological approach of religion. According to Raffaelle Pettazoni, this is an approach to religious issues by coordinating religious data, determining relationships and classifying data based on these relationships with typological comparisons between various religious phenomena (Dhavamony 1995:43; Pandor 2005:10-28).

Regarding cultural acculturation, following Heddy AhimsaPutra's (2012a:271-304) opinion, religion is one of the elements of culture that can influence other elements.

The National Park area is the area that the government preserves as a protected forest. The Bukit Duabelas forest has become the residence of several groups of the Orang Rimba community, especially in river beds (Makekal, Air Hitam, Kejasung, Terap, etc.).

This research reveals the historical roots of the formation of the Orang Rimba religion and its elements. The data collection methods used include observation and interview. Observations are used to see the rituals and pay attention to the mantras they recite in these rituals. Interviews are conducted to support the observation data on the readings they used. Furthermore, the collected data are analysed in depth, which is then interpreted in a report.

\section{Results of the research History and origin of the Orang Rimba}

Before this research was conducted, there was no definite explanation as to when and where the Orang Rimba first appeared. Zainuddin (2010:4-5) in his research entitled Sistem Kekerabatan Orang Rimba has mentioned several versions of origins of the Orang Rimba: firstly, the Orang Rimba are soldiers who got lost. At the time of the Jambi
Kingdom ruled by Putri Selaras Pinang Masak, the Kayo Hitam people attacked the kingdom and controlled Ujung Jabung (the Berhala Strait). When the attack overwhelmed Jambi, the Queen of Jambi asked King Pagaruyung for help. The king accepted her request by sending troops to Jambi through the jungle. When the troops arrived in the middle of the road (Bukit Duabelas), they ran out of supplies and thus could not continue their journey to Jambi. They could not also go back to Pagaruyung because it was a long way to go. They agreed to stay in Bukit Duabelas instead. Thinking of the embarrassment on the return to Pagaruyung and the punishment by the king, they vowed to stay in Bukit Duabelas on the condition that anyone who broke it would be cursed (Zainuddin 2010:4).

Secondly, the Orang Rimba came from the Minangkabau of West Sumatra. At first, they all huddled together until the arrival of the Dutch. Not wanting to be colonised by the Dutch, they fought back. However, as they could not resist, they ran away. Some of them ran downstream (to the sea) and some upstream (to the mountains). Those who went downstream became Minangkabau people, whilst those who went upstream became Orang Rimba.

However, according to the research conducted by the researcher, the Orang Rimba have been around for centuries. Long before the Dutch colonialism came Indonesia, the Orang Rimba were already there (Mr Jailani, Sumatra, 23 December 2013). Mr Besemen also confirmed that the Orang Rimba had existed before the Japanese occupation of Indonesia. He said that there were people from Dusun Baru during the Japanese colonial era; it was Muhammad who fled to the jungle being afraid of war. Muhammad then met and married Orang Rimba. Since then, Muhammad has remained and became the Tumenggung of Orang Rimba's community (Mr Besemen, Sumatra, 19 December 2013).

According to Jailani, the Orang Rimba are descended from kingdoms in Indonesia, such as the Srivijaya. Orang Rimba originated from a kingdom where they fled into the jungle because of a war or rebellion. Because they were already hiding and living in the jungle, they gradually felt they were at home and became Orang Rimba (Mr Jailani, Sumatra, 23 December 2013).

According to another theory, the Orang Rimba were scattered when the Sriwijaya Kingdom fell to Majapahit in 1350 AD. There was a commander from Bukit Duabelas named Sangsuto, whose wife Rangguto travelled with his followers to the Jambi border's forests. The commander gave birth to 10 children: nine boys (Bujang Sembilan) and one girl. Hence, the descendants of these children and grandchildren are called the Orang Kubu or the Orang Rimba (Simanjuntak 2008:12-13). When Jambi fought against the Dutch around the 19th century, the Jambi party was defended by the AnakDalam tribe led by Raden War's grandson Nagasri (Simanjuntak 2008:12-13). 


\section{Islamic philosophy in Orang Rimba's culture Mantra Madu}

This mantra is called the Mantra Madu [honey] because it is recited during the ceremony of taking honey from the Sialang tree which can reach 90 metres and higher. Someone must recite its mantra before climbing the Sialang tree. The mantra is read in two parts.

The first part of the mantra is as follows:

'Bismillahirohmanirrohima
Bismillahirohmanirrohima
Wah dating Api
Bukan beyuto punyo akar aku punyo akar
Bukan beyuto punyo batang aku punyo batang
Bukan beyuto punyo bungkul aku punyo bungkul
Bukan beyuto punyo daun aku punyo daun
Bukan beyuto punyo ranting aku punyo ranting
Bukan beyuto punyo daun aku punyo daun

Bukan beyuto punyo tali kelat aku punyo tali kelat

Bukan beyuto punyo sangkal lidi aku punyo sangkal lidi

Beyuto nyanya beyuto nyanyuk

Kabul kata Alloh

Setajab tibo di aku.' (Mr Besemen, Sumatra, 12 December 2013)

According to the Orang Rimba, doing every job must be started by reading basmallah. As stated by the chief of the tribe, '[i]f you do something, you must be bismillah'. When the researcher asked, 'where did the Orang Rimba get basmallah?', the chieftain replied, '... From God. Those are the only words from God. Because we have no books. Book is only held by Gods' (Chief of the tribe, 17 December 2013).

For the Orang Rimba, everything related to divinity must be kept secret, especially for outsiders who are not part of the group unless they are willing to become Orang Rimba. Only certain Orang Rimba know and can read it. Orang Rimba, who can recite this mantra, are called 'pious' people. A pious person is an elder in the jungle community and is considered to have significant knowledge (Mr Besemen, Sumatra, 19 December 2013); in Islam, they are called ulama.

The second part of the mantra reads as follows:

'Wastaghfirullohal'adhimtobat
Wastaghfirullohal'adhimtobat
Minta tobat ibu ke dengan Bapak
Blog minta ampun petang ke dengan pagi
Kabul pinta aku
Lebah jangan bagi menyengat lebah jangan bagi
Kalo nyempalo lebah menyengat
Nyompado kuno kusumpah siti Nabi Muhammad
Menyembah menyempuh di bawah telapak kakiku

Kariim yaa kariim turun tujuh sembruang

Kalo nentang, nentang sajo

Kalo nunduk, nunduk.' (Mr. Besemen, Sumatra, 12 December 2013)

This second mantra is even more impressive. This mantra is part of the Qur'anic words; even Prophet Muhammad's name is called in this mantra. These words are in the first and second lines, namely, the lafadz 'Wastaghfirullohal'adhim tobat', repeated twice. The first and second lines of the mantra above contain two essential elements: the word 'istighfar' and the word 'repentance'. In Islam, the word 'istighfar' means forgiveness (Surah Muhammad [47]:19).

However, the Orang Rimba does not identify Prophet Muhammad as the carrier of Islam with the Qur'an as the holy book. They only know Prophet Muhammad as the last prophet (Chief of the tribe, KebunKaret, Jambi, Sumatra, 17 December 2013). The word 'Karim', in the Qur'an, is mentioned in the Surah Saba' [34] verse 4.

The Orang Rimba do not know the Qur'an, but some of their mantras contain Qur'anic verses. This strengthens their statement that some of their ancestors came from West Sumatra, who had already embraced Islam when they left their village. Because they were isolated in the forest and focused on survival, they did not develop an understanding of the Qur'an.

\section{Orang Rimba and five pillars of faith}

When the researcher lived and got to know the Orang Rimba, he found Islam there. The data found by the researcher point to the religion of the Orang Rimba as Islam. The researchers found that the Orang Rimba also believe in the pillars of faith, as do the Muslims. It is just that the element of faith does not contain faith in the Scriptures and Allah's destiny. Perhaps it is because of the disruption of the culture of text, writing and reading, especially with the outside world.

When the researcher followed the head to motong [taking gums] the rubber in his garden, he told the researcher that the Orang Rimba also had faith in Allah as their God, Prophet Muhammad as his messenger and belief in angels. Even the Orang Rimba also have faith in the arrival of the Day of Judgment. He said that God must protect all creatures on the earth, take care of humans, take care of animals and protect nature. God commands people to do good and leave evil. All human deeds will be rewarded by God there (hereafter) (Chief of the tribe, 17 December 2013).

He also said that everyone before going to heaven must go through hell, '[l]ater in hell, there will be a bridge called the "Noroton footbridge"'. This walkway was sharp like a knife (Chief of the tribe, 17 December 2013). Mr Besemen also told the researcher that in the afterlife, humans would pass through hell with a bridge: 
'...There is a bridge to hell. Under the bridge, there was a fire. If we were right on the bridge and sinned, we would fall. How long, I don't know. ....' (Mr Besemen, Sumatra, 19 December 2013)

The section of the interview above is interesting to observe. The words of Mr Besemen above contained the words ' Padang Mahsyar'. In Islam Padang Mahsyar is understood as a place of gathering for humans after being revived from the grave. Here, they will judge or calculate their deeds and the retribution of all deeds whilst living in the world (Kuthb 2003:70). In Islam, Padang Mahsyar is life in the hereafter that Muslims must believe (Taufik 2003:206).

In Padang Mahsyar, humans are assembled before being led through hell. In the belief of Orang Rimba, people who do sin will fall into hell. It is in that hell that sinners will be cleansed of their sins before entering heaven. After humans are cleansed from their sins, they enter heaven and live forever (Chief of the tribe, 17 December 2013). And as long as there is sin in humans, they will continue to be burned in hell (Mr Besemen, Sumatra, 19 December 2013).

\section{Ratib reading in the death ceremony}

The recitation of the Ratib mantra is done before the funeral is held. Interestingly, in the recitation of this mantra, what is read is the shahada sentence, namely Laa Ilaaha Illallah. One example of a fragment from the Ratib reading is presented here.

\section{Death Ratib mantra:}

'Laa Ilaaha Illallah//Laa Ilaaha Illallah//O, God!/Save my Grandma' (Jailani, Sumatra, 23 December 2013 and Mr Besemen, Sumatra, 20 December 2013)

In the above mantra, the phrase Laa Ilaaha Illallah means 'there is no god but Allah'. In Islam, this word is known as the kalimah shahada. The phrase Laa Ilaaha Illallah that is contained in the death Ratib of the Orang Rimba is also mentioned in the Qur'an, Surah Muhammad [47] verse 19. Hamka (2015:315) interprets Laa Ilaaha Illallah as 'there is no God but Himself. Therefore there is nothing worthy to be adored and worshipped but Him'. It is an affirmation of monotheism. The chief of the tribe also said that God is only one; he has neither child nor food. His statement in Islamic teachings is known as Tawheed, which is to affirm Allah (see Surah Al-Ihalas [112]:1-4). The chief of the tribe further said, ' $[w]$ hen we sin, other people don't know. But God sees. That is faith' (Chief of the tribe, 17 December 2013).

The interment ceremony which is conducted by the Orang Rimba is almost the same as the teachings of Islam. At least three principles are the same as in Islam when the Orang Rimba want to bury their bodies. In their tradition, when a community member dies, they must first bathe the body until it is clean before it is shrouded and buried. Similarly, in Islam, it is mandatory to wash the body before it is converted. In the Orang Rimba tradition, the bodies of the dead people are covered in three layers of cloth for men and five layers for women (Ary in Bukit Duabelas, Sumatra, 15 December 2013).
Muslims also perform the same ritual as that of the Orang Rimba before a dead person is buried, namely, covering the body (Al-Albani 1999:28).

In Islam, after washing and being bathed, the next step is to pray the body. Meanwhile, this is almost the same in the Orang Rimba community, but they do not pray as Islam does. As for what the Orang Rimba do, they read the Ratib, Laa Ilaaha Illallah. However, the reading of this Ratib is only for an Orang Rimba who dies in old age. When an Orang Rimba's body is buried, it must be turned to the west. Because, according to the Orang Rimba, facing west means facing the Qibla. The Qibla for the Orang Rimba is the Kaaba, and it faces west (Mr Besemen, Sumatra, 20 December 2013). The Orang Rimba also believe in the 'Kaaba', even though they do not know where it is. They only assume that the Kaaba exists and becomes the direction for the Orang Rimba (Chief of the tribe, 17 December 2013).

In Islam, the same is also followed when burying a body, namely, facing the body towards the Qibla (west) with its head in the north. The difference between Islam and Orang Rimba is that in Islam, the body is buried in the ground, whilst the Orang Rimba do not bury a corpse in the ground but instead make a house on stilts. The body is laid out on the stilt house (Chief of the tribe, 17 December 2013).

\section{Berdekir ceremony}

Berdekir is interesting because this term is almost the same as the term used in Islam, namely ' $d h i k r$ '. Meanwhile, in the Orang Rimba version, standing is how the Orang Rimba worship or pray gods. However, worship of this God is not a form of worshiping a god because the gods for Orang Rimba are only helpers, not God. The purpose of worshiping the gods in this stand is to worship God. Because God might be too sacred for the Orang Rimba and too far away to be reached, standing up is the only way for them to get closer to their God, because for the Orang Rimba, the gods' existence is the same as the existence of angels who help God (Mr Besemen, Sumatra, 19 December 2013).

The Orang Rimba's Berdekir is usually carried out for a full week from eight in the evening to five in the morning. Orang Rimba stand in a Bale, a place made as a place of worship for the Orang Rimba. They do not arbitrarily choose a place to build a Bale. Usually, a Bale is set up in an area surrounded by large trees. Besides, the place must also be roomy. Bale, which measures about $7 \mathrm{~m} \times 7 \mathrm{~m}$ with a height of about $1.5 \mathrm{~m}$, made a model stage. This Bale is made without a roof.

It becomes interesting to listen to the chants of the Berdekir mantras used by the Orang Rimba. In the ceremony, Orang Rimba mention several words that are synonymous with Islam, including Assalamualaikum, bismillah, Allah, Muhammad, Adam, Hawa and so on. The Orang Rimba admitted that 
Adam was the first prophet and Muhammad was the last prophet (Mr Besemen, Sumatra, 19 December 2013).

Unfortunately, the researcher was unable to present a complete example of the mantra verse in this Berdekir ceremony. Because this mantra, according to the Orang Rimba, is very secret, only an Orang Rimba knows it. Outsiders are strictly prohibited from seeing and attending the Bale ceremony. According to $\mathrm{Mr}$ Besemen, outsiders can only attend the ceremony at the stand in Bale when the outsider has joined and has become a resident of the jungle. When an outsider claims to join and become an Orang Rimba, he or she must follow all the jungle customs. Everything that has to do with the outside world must be abandoned. Now, when an outsider has become an Orang Rimba, he or she can only attend the Bale ceremony.

\section{Discussion \\ Orang Rimba's religion}

Until this research was conducted, no one knew the exact name of this Orang Rimba religion. Some say that the Orang Rimba have no faith, whilst others say that the Orang Rimba adhere to polytheism. According to Hardjana (1993:25), polytheism is an understanding that believes in and worships many gods.

According to some researchers, the Orang Rimba religion is animistic. Animism believes in the existence of spirits and spirits that inhabit the entire universe (Hadiwijono 2006:4). The theory of animism assumes that the origin and basis of human religion are the belief in the existence of spirits and spirits who occupy all of nature (Koentjaraningrat 1958:148).

Other researchers argue that the Orang Rimba religion is dynamism. Dynamism believes in the existence of supernatural powers that can occupy any object (ed. Adelowo 2014:98). Rudolf Otto, a religious historian from Germany, as quoted by Karen Amstrong in her famous book A History of God: The 4000-Year Quest of Judaism, Christianity and Islam, said that belief in the unseen (numinous) is the basis of religion (Armstrong 2011:29).

When the researchers conducted this research, they found a great deal of evidence that the Orang Rimba is a society with the belief in supernatural powers outside of themselves. This became clear when the researcher asked them, 'who is protecting this jungle?' They answered, 'Dewo' (Mr Meratai, a member of the Orang Rimba, 14 December 2013).

On the one hand, the Orang Rimba believe in gods who occupy certain places, such as rivers, trees and animals. They also believe in tiger god, honey god, elephant god, pangolin god, disease god, cat god and rice god (Ary, Sumatra, 15 December 2013).

On the other hand, the Orang Rimba also believe in spirits or spirits who inhabit certain places. It is evidenced by the Orang Rimba's belief in spirits that can rise again for specific reasons. For example, according to the Orang Rimba belief, if it rains at the Orang Rimba burial ground at midnight, the spirits of the buried bodies are believed to rise and become spirits (Sepintak at the KKI Warsi Camp, Sumatra, 17 December 2013).

The belief in the existence of spirits is also evident from the Orang Rimba's religion about the prohibition of killing animals whilst they are drinking. According to Tumenggung Maritua, an animal drinking means that the animal is merging with the ancestors' spirits. Therefore, when an animal is drinking from the river, it is strictly forbidden to kill it. It became clearly known from this fact that the Orang Rimba were also animists (Maritua at Sungai Terap, Sumatra, 23 December 2013).

At first, the researchers thought that they also embraced animism. However, exciting and surprising is the fact that when the researchers did more in-depth data exploration in the jungle with them, they found that the Orang Rimba embraced religion with the concept that God is one, which is known as monotheism (i.e. the doctrine or belief that there is only one God) (Neufeld 2015:xiii; Smith 2010:164).

According to the Orang Rimba, their God was not these spirits or gods. As Mr Jailani stated, their God is still one. He said:

'... If we follow the rules, then a hundred flowers will be a hundred Idols, who must obey. But that's not God, and they claim as Idols, not God. God is Allah. He is the only one.' (Mr Jailani, Air Hitam Group, Jambi, Sumatra, 23 December 2013)

Therefore, the gods they worship are not God, as society and government have thought so far. For the Orang Rimba, these gods' existence is believed to be only a helper, not the essence of God who creates. For them, God was not the gods who are worshiped. The gods who are worshipped are only intermediaries that connect humans with their God (Chief of the tribe, 17 December 2013). The duties of the gods worshipped by the Orang Rimba are as helpers, such as the tiger god, whose job is to help the Orang Rimba in protecting the forest. The elephant god is believed to help the Orang Rimba in treating diseases, and so on (Ary, Sumatra, 15 December 2013). That is the opinion of the Orang Rimba. When asked, they only say that the gods they have been worshiping are not their gods. They said that their God is only one, Allah (Mr Jailani, Sumatra, 23 December 2013). Of course, this understanding is not animism or polytheism, but monotheism, that is, belief in the existence of one God or God Almighty. In Islamic terms, it is called Tawheed.

In addition to adhering to a single Godhead, what is interesting is that the Orang Rimba also know and have faith in Prophet Adam as the first prophet and Prophet Muhammad as the last prophet; they also see the existence of Kaaba and believe in the existence of angels. They also believe in Doomsday's arrival and the presence of heaven and hell (Chief of the tribe, 17 December 2013). 
The norm in the funeral ceremony is that when an Orang Rimba dies a mantra must first be recited. They call the mantra the reading of Ratib. What is surprising is that the Ratib mantra contains a fragment of the sentence Laa Ilaaha Illallah (Mr Besemen, Sumatra, 20 December 2013). This discovery is new evidence that can undermine the old theory that has been held so far, namely that the Orang Rimba are adherents of animism.

Emile Durkheim says that there are three conditions for animist beliefs and practices to be categorised as the original form of religious life: firstly, because in the hypothesis, the idea of the soul becomes the most crucial idea of religion; secondly, one has to show how this idea came to be without taking elements of this idea from previous religions; and thirdly, because the mode of worship is not religion as a whole, how nature worship can emerge from the worship of spirits must also be explained (Durkheim 2011:83). The Orang Rimba also do not worship nature because they believe in the existence of these spirits. They only assume that the ancestral spirits exist and are not worshiped as an implementation of God's manifestation.

\section{Islam Rimba: Met two culture elements}

The data presented above indicate the acculturation of religion and culture in the Orang Rimba belief system. According to Ahimsa-Putra (2012:254), acculturation is a process that occurs when one culture meets another culture and then takes a number of new cultural elements and transforms them in such a way that they look like their own cultural elements.

From the studies that researchers have conducted, at least two cultural values meet in the Orang Rimba religion: firstly, Islamic values with the Al-Qur'an as its basic principles and, secondly, the cultural values of the Orang Rimba with their customs and everything that surrounds them. The principles of Islamic teachings blend with the Orang Rimba culture so that these Islamic principles appear like the Orang Rimba culture itself. The combination of these two cultural elements later became the Orang Rimba religion.

Revealing historical facts about the origin of the Orang Rimba can answer this question because the history of the Orang Rimba sources has influenced the formation of the religion that the Orang Rimba practise today. The Orang Rimba had existed long before colonialism came to Indonesia. It is even said that when the Dutch and Japanese colonialists came to Indonesia, the Orang Rimba were already there (Mr Jailani, Sumatra, 23 December 2013; Mr Besemen, Sumatra, 19 December 2013). The Orang Rimba are descended from kingdoms that once existed in Indonesia, such as the Srivijaya Kingdom (Muljana 2006:306). Because of war, some of the king's people fled into the forest to hide and finally settled in the forest and became the Orang Rimba. Historical facts also confirm Mr Jailani's statement. The Orang Rimba forerunners began to spread when the Sriwijaya Kingdom fell to Majapahit in 1350 AD (Simanjuntak 2008:12).

The Dutch first came to Indonesia in 1552 under Cornelius de Houtman's leadership. At that time, Cornelius landed in the port of Banten, which was the centre of power in the archipelago (Resink 2013:35). It means a 202-year gap between the fall of the Srivijaya Kingdom by Majapahit in $1350 \mathrm{AD}$ and the first Dutch arrival in the archipelago in 1552. Meanwhile, Jambi's war against the Dutch happened around the 19th century. The Jambi party had been assisted by the Orang Rimba led by Raden War and the grandson of Nagasri (Resink 2013:72). Two hundred and two years is not a short time. There was a moment when Mr Jailani stated that the Orang Rimba had children and grandchildren when the Dutch came to colonise Jambi.

One of the theories about Islam entering Sumatra is that Islam entered Indonesia in the 7th century AD (1st century Hijrah). At that time, the Srivijaya Kingdom developed power around the 7th and 8th centuries, and also, in the Malacca Strait had started passing traders, and the Muslim traders had begun their voyage to countries in Southeast Asia and East Asia (Indonesia) (Harun 1995:1), spreading Islam in Southeast Asia and the Indonesian archipelago since the 12th or 13th century (Graaf \& Pigeaud 1986:18).

In the 7th century AD, Jambi Melayu was controlled by the Srivijaya Kingdom. We can estimate that Islam had begun to be widely spread throughout the archipelago, including Jambi and its surroundings. The kingdom's role in Nusantara cannot be separated from the spread of Islam, especially the Srivijaya Kingdom. What is more is that, in Sumatra in the 17th century, Sultan Iskandar Muda (1607-1636) extended his power to the Peninsula and the West Coast of Sumatra. It was during the reign of Iskandar Muda that Islam in Indonesia began to develop rapidly. It is evidenced by the discovery of Arabic texts written by scholars from Sumatra, especially from Aceh, one of which is the interpretation of Surah al-Kahfi [18]:9 (Zuhdi 2014a:8). The tradition of interpreting the Qur'an in Indonesia has been started since the 17th century, namely, the evidence of the discovery of the text of the Tafsir Surat al-Kahfi [18] verse 9 (Feener 1998:47; Riddell 2017:20).

If we count from the 7th century AD when Islam first started to enter Indonesia until the 19th century when Jambi fought the Dutch, there is a gap of 12 centuries. It means that Islam has entered Indonesia since a long time and has spread compared to the arrival of the Dutch in Indonesia. During evacuation to the Bukit Duabelas forest because of war between the Srivijaya Kingdom and the Majapahit Kingdom (1350), the people who fled to the Bukit Duabelas forest were thought to have known Islam. Because the understanding of Islam was still minimal, it was brought into the jungle and integrated with the jungle culture. Since then, the acculturation of the Orang Rimba religious culture has begun to take shape. 
Because the refugees caused by the war between the Srivijaya Kingdom and the Majapahit Kingdom occupied the jungle, their interactions with the outside world were cut off, especially with the holy book texts' civilisation. They only believe in the four pillars of faith: faith in Allah, belief in angels, faith in apostles/prophets (Muhammad and Adam) and faith in Judgment Day. Naturally, if one looks closely, the Islamic values that blend with the jungle culture - as described above - are only elements of the pillars of faith.

The inadequate understanding of Islam then mixes and blends with life in the jungle far from Islamic values. Because they are cut off from the holy book civilisation and do not know the pillars of Islam, the Orang Rimba do not know the principles of Islamic law, especially those related to commands and prohibitions. That is why the Orang Rimba do not know the prayer, fasting, zakat, pilgrimage and so on.

The statement of Mr Jailani in the following reinforces it:

'... The Orang Rimba are all Muslims. All these Orang Rimba originate from Muslim ancestors. Look at them talking about; they said "Oh Allah". They want to do there is no teacher. The teacher is not there, runs to the jungle, hungry, what is found is eaten. So, they don't know what haram is and what is lawful anymore. Idols are idols, not God ...'). (Mr Jailani, Sumatra, 23 December 2013)

The meeting of these two cultural elements makes the Orang Rimba religion unique. Some have Islamic aspects, and some others are elements of jungle culture. Since then, the cultural acculturation between Islam and the jungle culture was built. These two cultural elements then merged and became the Orang Rimba religion. From here, the writer calls the Orang Rimba religion by the term 'Islam Rimba'. So there may be some truth if Antoine Cabaton mentions that the Kerinci people, who live in the country surrounding Indrapura and are supported by Malays from Minangkabau, are mostly Muslims, even though, in reality, they are animists (Cabaton 2015:301).

These elements of Islamic culture are not only visible in religious life but also affect the language used. According to Simanjuntak, the Orang Rimba language is ancient Malay (proto Malay) (Simanjuntak 2008:246). Malays write with Arabic letters modified to suit their own alphabet, and many Arabic letters are integrated into Malay (Marsden 2013:231). This is what is called cultural acculturation (Ahimsa-Putra 2012:254). The Islamic principles, which are an integral part of the Orang Rimba religious system, seem to emphasise that the spread of Islam has reached Bukit Duabelas. This finding appears to emphasise that the Orang Rimba are Muslims.

Thus, the religiosity of Orang Rimba can be called a Muslim phenomenon in Indonesia. It can be classified as contextual Islam, born as a result of unfavourable situations and conditions. However, the religiosity of Orang Rimba cannot be justified as true Islam. Therefore, it is the duty of the Da'I in realising the Islam of the Orang Rimba to guide them to the true Islamic teachings.

\section{Conclusion}

The Orang Rimba are adherents of monotheism, not animism, polytheism or dynamism, as understood so far. The concept of Orang Rimba's divinity is the belief that God is one. The Islamic culture and the jungle culture elements influence the formation of the Orang Rimba religion. The evidence that Islam was one of the elements that influenced the formation of the Orang Rimba's religion is the 'Islamic Tradition' found in their customs and culture.

This discovery confirms that the Orang Rimba is originally from Islam. It is familiar with Islam before entering the forest. However, because of a limited understanding of Islam and a disconnection from the holy book text's civilisation, Islam that appears in the Orang Rimba community is the only Islam that practises the pillars of faith. Meanwhile, they do not understand the pillars of Islam. This discovery proves the existence of a new theory about the spread of Islam in the SAD community that has occurred before the 14th century and at the same time undermines the old theory about the Orang Rimba religion that has been misunderstood so far.

\section{Acknowledgements Competing interests}

The authors declare that they have no financial or personal relationships that may have inappropriately influenced them in writing this article.

\section{Authors' contributions}

W.W. prepared the concept, methodology and formal analysis; M.N.Z. wrote the original draft, investigated and did the administration. W.W. supervised the research. M.A.N. and E.E. completed the writing, review and editing of the article. M.A.N. translated the SAD's language into Indonesian. E.E. edited and translated the manuscript into English. M.A.N. assisted E.E. and M.N.Z. in the investigation of Jambi and doing administration in Jambi. E.E., M.A.N., W.W. and M.N.Z. discussed reviewers' comments and revised the article together. All authors read and approved the final version of the article to be published.

\section{Ethical considerations}

This article followed all ethical standards for research.

\section{Funding information}

This research is funded by the Ministry of Religious Affair of Indonesia in Program Research Competition 2013.

\section{Data availability}

The data that support the findings of this study are available upon reasonable request from the corresponding author. 


\section{Disclaimer}

The views and opinions expressed in this article are those of the authors and do not necessarily reflect the official policy or position of any affiliated agency of the authors.

\section{References}

Abdurrahman, D., Maryam, S., Sodiqin, A., Herawati, M., Imam, Firdaus, Irfan, 2012 Sejarah Peradaban Islam: Dari Masa KlasikHingga modern, Lesfi, Yogyakarta.

Adelowo, E.D. (ed.), 2014, Perspectives in religious studies, vol. 1, Hebn Publishers, Nigeria.

Ahimsa-Putra, H.S., 2012a, 'The living Al-Qur'an: Beberapa Perspektif Antropologi', Walisongo: Jurnal Penelitian Sosial Keagamaan 20(1), 235-260. https://dol. org $/ 10.21580 /$ ws.20.1.198

Ahimsa-Putra, H.S., 2012b, 'Fenomenologi Agama: Pendekatan Fenomenologi Untuk', Walisongo 20(2), 271-304. https://doi.org/10.21580/ws.2012.20.2.200

Al-Albani, N., 1999, Tuntunan Lengkap Mengurus Jenazah, ed. A.M. Basalamah, Gema Insani Press, Jakarta.

Armstrong, K., 2011, Sejarah Tuhan: Kisah 4000 Tahun Pencarian Tuhan Dalam Agama-Agama Manusia, 3rd edn., ed. Z. Am, PT Mizan Pustaka, Bandung.

Cabaton, A., 2015, Jawa, Sumatera Dan Kepulauan Lain Di Hindia Belanda, ed. A. Handayani, dkk, Penerbit Ombak, Yogyakarta.

Dhavamony, M., 1995, Fenomenologi Agama, Kanisius, Yogyakarta.

Durkheim, E., 2011, The elementary forms of the religious life, ed. I.R. Muzir, IRCiSoD, Yogyakarta.

Feener, R.M., 1998, 'Notes towards the history of Qur'anic Exegesis in Southeast Asia', Studialslamika: Indonesian Journal for Islamic Studies 5(3), 47. https://doi. org/10.15408/sdi.v5i3.739

Graaf, H.J. De, \& Pigeaud, G.T., 1986, Kerajaan-Kerajaan Islam Pertama Di Jawa, PustakaGrafiti Pers, Jakarta.

Hadiwijono, H., 2006, Religi Suku Murba Di Indonesia, Gunung Mulia, Jakarta.
Hamka, 2015, Tafsir Al-Azhar: Karya Agung Ulama Nusantara, 1st edn., PTS Publishing House, Malaysia.

Hardjana, A.M., 1993, Penghayatan Agama: Yang Otentik Dan TidakOtentik, Kanisius, Yogyakarta.

Harun, Y., 1995, Sejarah Masuknya Islam Di Indonesia, Kurnia Alam Semesta, Yogyakarta.

Koentjaraningrat, 1958, Beberapa Metode Antropologi Dalam Menjelidikan 2 Masjarakat Dan Kebudajaan Di Indonesia: Sebuah Ichtisar, Universitas, Djakarta.

Kuthb, S., 2003, Tafsir Fi Zhilal Al-Qur'an: Di Bawah Naungan Al-Qur'an, 5th edn., ed. A. Yasin dkk, Gemalnsani Press, Jakarta.

Marsden, W., 2013, Sejarah Sumatera, Terj: Tim KomunitasBambu, Komunitas Bambu, Jakarta.

Muljana, S., 2006, Sriwijaya, ed. M. Al-Fayyad, LKiS, Yogyakarta.

Neufeld, D., 2015, The mythology of Judaism: The history and development, Meteor Content Providers, s.l.

Pandor, P., 2005, 'Fenomenologi Agama Menuju Penghayatan Agama Yang Dewasa' Arete 1(1), 10-8. http://journal.wima.ac.id/index.php/ARETE/article/view/167.

Resink, G.J., 2013, Bukan 350 TahunDijajah, Komunitas Bambu, Depok.

Riddell, P.G., 2017, Malay court religion, culture and language: Interpreting the Qur'an in 17th century Aceh, Brill, Leiden.

Simanjuntak, M., 2008, Selayang Pandang Anak Lintang Bukit Barisan Suku Tobo Atau Kubu, Kolportase Pusat Gereja Kristen Protestan Indonesia, Pematang Siantar

Smith, M.S., 2010, God in translation cross-cultural recognition of deities in the biblical world, Wm. B. Eerdmans Publishing, Grand Rapids, MI.

Taufik, A., 2003, Negeri Akhirat: Konsep Eskatologi Nuruddin Ar-Raniri, PT Tiga Serangkai Pustaka Mandiri, Solo.

Zainuddin, 2010, Sistem Kekerabatan Orang Rimba, KomunitasKonservasi IndonesiaWarung Informasi, Jambi.

Zuhdi, M.N., 2014, Pasaraya Tafsir Indonesia: Dari Kontestasi Metodologi Hingga Kontekstualisasi, Kaukaba Dipantara, Yogyakarta. 